\title{
The benefits of omega-3 fatty acid nanocapsulation for the enrichment of food products: a review
}

\author{
Os benefícios da nanoencapsulação de ácidos \\ graxos da classe ômega-3 para o enriquecimento \\ de produtos alimentícios: uma revisão
}

\author{
Maiana da Costa VIEIRA ${ }^{1}$ (ID) 0000-0002-1061-3228 \\ Karstyn Kist BAKOF² ID 0000-0002-2290-0558 \\ Natielen Jacques SCHUCH² ID 0000-0001-7963-2104 \\ Jovito Adiel SKUPIEN² ID 0000-0003-0892-3048 \\ Carina Rodrigues BOECK ${ }^{1}$ ID 0000-0002-6828-5634
}

\section{A B S T R A C T}

Polyunsaturated fatty acids oxidize easily due to their chemical structure, causing a reduction of their nutritional properties. Nanostructured systems may be an alternative to protect fatty acids against oxidation, improving solubility and stability. Consequently, nutritional value of food is maintained as well as the sensory characteristics (color, flavor, texture, and aroma) when fatty acids are added to food products. The present study is a narrative review to introduce the potential benefits of omega-3 unsaturated fatty acids nanoparticles incorporated in food products. The literature review includes publications in English and Portuguese issued between March 1985 and March 2019, in PubMed, ScienceDirect and Web of Science databases. Manual searches were conducted in the articles references lists of the articles included to identify other relevant studies. There were studies that evaluated the stability of fatty acids in food products such as bread, fruit juice, milk, yogurt, and meat. In this study, the most used nanostructured systems for the incorporation of fatty acids were the nanocapsules and the nanoliposomes. Currently, the nanostructured system demonstrates a potential to improve protection of polyunsaturated fatty acids against oxidization and thermal degradation. In this way, they maintain their functional properties and their bioavailability increases and therapeutic efficacy and sensory properties are improved. There are several

1 Universidade Franciscana, Pró-Reitoria de Pós-Graduação e Pesquisa, Programa de Pós-Graduação e em Nanociências. R. Andradas, n. 1614, Centro, 97010-032, Santa Maria, RS, Brasil. Correspondence to: C.R. BOECK. E-mail: <cariboeck@hotmail.com>.

2 Universidade Franciscana, Pró-Reitoria de Pós-Graduação e Pesquisa, Mestrado em Ciências da Saúde e da Vida. Santa Maria, RS, Brasil.

Article elaborated from thesis by M.C. VIEIRA, entitled "Estudo da eficácia da nanoencapsulação de ácidos graxos insaturados da classe ômega-3 como proteção à oxidação: uma revisão sistemática e metanálise”. Universidade Franciscana; 2019.

How to cite this article

Vieira MC, Bakof KK, Schuch NJ, Skupien JA, Boeck CR. The benefits of omega-3 fatty acid nanocapsulation for the enrichment of food products: a review. Rev Nutr. 2020;33:e190165. https://doi.org/10.1590/1678-9865202033e190165 
methodologies being tested, which makes it difficult to identify the most efficient formulation to protect fatty acids. Nanostructured systems seem to be the best alternative to protect polyunsatured fatty acids from oxidization. The encapsulation efficiency, particle's size and type are relevant factors to be considered to evaluate oxidization. In conclusion, the review showed that currently it is impossible to determine the most efficient methodology. Besides, nanoformulations should follow international guidelines to present more standardized and therefore more efficient particles.

Keywords: Functional food. Omega-3. Nanotechnology. Unsaturated fatty acids.

\section{RE S U M O}

Os ácidos graxos poli-insaturados são facilmente oxidados devido à sua estrutura química, o que acarreta a diminuição de suas propriedades nutricionais. Nesse contexto, o sistema nanoestruturado pode ser uma alternativa para protegê-los contra a oxidação, melhorando a solubilidade e estabilidade. Consequentemente, quando são adicionados a produtos alimentares, o valor nutricional é mantido, bem como as características sensoriais (cor, sabor, textura e aroma). O presente estudo é uma revisão narrativa para apresentar os potenciais benefícios das nanopartículas com ácidos graxos insaturados da classe ômega-3 incorporados a produtos alimentícios. A literatura consultada incluiu publicações em inglês e em português, considerando o período entre março de 1985 e março de 2019, utilizando as bases de dados PubMed, ScienceDirect e Web of Science. Foram realizadas buscas manuais nas referências dos artigos incluídos, a fim de identificar outros estudos relevantes. Foram encontradas pesquisas que avaliaram a estabilidade dos ácidos graxos em produtos alimentícios, como pães, suco de fruta, leite, iogurte e carne. Neste estudo, as nanoestruturas mais utilizadas para a incorporação dos ácidos graxos foram as nanocápsulas e os nanolipossomas. Atualmente, o sistema nanoestruturado demonstra um potencial para melhorar a proteção desses ácidos poli-insaturados contra a oxidação e degradação térmica. Dessa forma, eles mantêm suas propriedades funcionais, aumenta-se sua biodisponibilidade e há melhora da eficácia terapêutica e das propriedades sensoriais. Existem diversas metodologias sendo testadas, o que dificulta a identificação de qual seria a formulação mais eficiente nessa proteção, mas os sistemas nanoestruturados parecem ser a melhor alternativa para proteger os ácidos graxos insaturados da oxidação. A eficiência de encapsulação bem como o tamanho e o tipo de partícula são fatores importantes a considerar na avaliação da oxidação. Em conclusão, a revisão demonstrou que atualmente a metodologia mais eficiente não é possivvel de ser identificada. Ademais, as nanoformulações devem seguir diretrizes do protocolo internacional para apresentar partículas mais padronizadas e, assim, eficientes.

Palavras-chave: Alimentos funcionais. Ácidos graxos ômega-3. Nanotecnologia. Ácidos graxos insaturados.

\section{INTRODUCTION}

The incidence of diseases such as cancer, stroke and cardiovascular events, arteriosclerosis and liver disorders is closely associated to the diet, and can be minimized through good eating habits [1]. Functional foods provide health benefits; when they are part of the diet; in addition to their nutritional functions, metabolic and physiological effects on the body inherent to their chemical composition, reduce the risk of chronic-degenerative diseases [2]. Thus, the interest in healthy eating and the scientific evidence of the effects of functional foods on health make the consumption of these foods a health promotion strategy [3]

The enrichment of foods with functional food components, that is, nutraceutical products, can improve food properties. However, the effectiveness in promoting health with the use of this practice depends on the preservation, functionality and bioavailability of the nutraceuticals used [4]. In this connection, nanotechnology has been used in recent years in the food industry to improve more effectively the desired food functional properties [5].

In fact, nanostructured systems applied to food combine scientific research with innovation in the food industry, making it a field that has grown swiftly in the past decade. This is due to the 
fact that, originally, nanotechnology is multidisciplinary because it uses a set of techniques that allows harness and manipulation of particles (in this case, containing bioactive compounds) that are in extremely small dimensions. Hence, a modification of the chemical, mechanical, electrical, optical and/or magnetic properties that are significantly different from the properties of the same compounds on a macro scale takes place. Often the nanoscale compound can have its physical-chemical stability improved and the biological properties increased in terms of effect, bioavailability and site of action $[5,6]$.

Nanomaterials, by definition, are comprised within the scale of 1 to 100 nanometers, in at least one of their dimensions, so that the use of their properties is dependent on the size and structure, and phenomena, different from those associated with isolated atoms or molecules, or even the same material on a macro scale $[7,8]$. Thus, some of the applications yield nanostructured materials in the food.

This innovation can also be applied to influence the macroscale characteristics of foods, such as texture, flavor, other sensory attributes, coloring, processability and stability during shelf life, thus leading to a large number of new products. Furthermore, this nanoencapsulation technology can also improve the solubility of lipophilic compounds in water, the chemical and thermal stability, the bioavailability of bioactive compounds and controlled release, which is extremely interesting for vitamins, minerals, polyunsaturated fatty acids, polyphenols, carotenoids and probiotics $[9,10]$.

Omega-3 essential fatty acids are a class of nutraceuticals under study for food enrichment due to their functional properties. The concept of essential fatty acids comes from the fact that they are essential lipids for the human body due to their cellular functions associated with inflammatory and immunological reactions; in addition, they cannot be synthesized endogenously, requiring their ingestion. The main classes of essential fatty acids are omega- 3 and -6 , represented by the major compounds in foods: Alpha-Linolenic Acid (ALA, C18:3) and Linoleic Acid (LA, C17:2), respectively [11]. In the omega-3 class there are long-chain polyunsaturated fatty acids that have received attention due to their relevance for their preventive effect against cardiovascular diseases: they are the Docosahexaenoic Acids (DHA, C20:5) and Eicosapentaenoic Acids (EPA, C22:6, n-3). Omega-3s have anti-inflammatory, antiarrhythmic, vasodilatory effects, and are also active in dyslipidemia, diabetes Mellitus and obesity, with important cardioprotective effects [12].

The presence or inclusion of omega-3 in food systems can be considered a challenge for the food industry, due to its polyunsaturated structure highly prone to oxidation, which can cause undesirable flavors and odors in the products. The challenge is then to protect omega-3 beneficial properties by using natural ingredients in the formulations [13].

Nanostructured systems are a promising alternative to protect omega fatty acids against oxidation by improving solubility and stability, thus maintaining food products with their nutritional value and sensory characteristics (color, flavor, texture and aroma). In this framework, this article presents a review of the potential benefits of omega-3 fatty acid nanoencapsulation for the enrichment of food products.

\section{METHO D S}

The present study is a narrative, descriptive review on the use of nanoencapsulated omega-3 polyunsaturated fatty acids added to food products, focusing on the potential benefits of nanoencapsulation in protecting lipid from oxidation and preserving the sensory properties of food. 
Articles from journals published in English or Portuguese between March 1985 and March 2019, retrieved in the Scientific Electronic Library Online (SciELO), National Library of Medicine (PubMed), ScienceDirect and Web of Science databases were accessed. The search delimiting descriptors were: nano* and unsaturated fatty acids or omega-3 or polyunsaturated fatty acids and foods.

To make the search comprehensive, the lists of references obtained from the databases were evaluated. The full text articles of the selected studies were obtained and reviewed seeking information related to application in food, and incorporation in food products. The whole process involved search activities, exploratory reading of titles and abstracts, selection of studies that were considered adequate to the objectives of this study, complete analysis of the texts and, finally, the performance of interpretive reading and writing.

\section{RESULTS AND DISCUSSION}

The growing industrialization of food, together with changes in the eating habits, led to an increase in the consumption of fats and oils, which are often composed of saturated fatty acids, trans unsaturated fatty acids and, on the other hand, decreased the consumption of polyunsaturated fatty acids, especially Omega $3[1,14]$. In the 1970s, the first studies emerged showing the health benefits of a diet rich in omega-3 polyunsaturated fatty acids. The beneficial effects of omega-3 intake were verified in a study carried out with the Greenland Eskimos, which revealed a high consumption of a diet rich in marine mammals and fish and a low rate of cardiovascular diseases, asthma and type II diabetes Mellitus [15].

The consumption of omega-3, in particular DHA, has a protective effect against some types of cancer such as breast, colon and prostate cancer. Studies also reveal that the consumption of these fatty acids plays a fundamental role in the development and function of the central nervous system, reproductive system, in the prevention of cardiovascular diseases, blood pressure, improvement of endothelial function, stabilization of atheromatous plaque and have several effects on the immune and inflammatory response $[16,17]$.

The high consumption of fats is associated with the increase in cardiovascular diseases, which are among the main causes of death in the world, estimated at about $30 \%$ of worldwide mortality [1]. The consumption of polyunsaturated fatty acids is recommended in several guidelines, which may vary according to the country and between different regulatory institutions, some of which are still under discussion, and are shown below.

The recommended daily doses for adults of omega-3 EPA and DHA range from 180-500mg for the prevention of heart disease and may reach up to $1 \mathrm{~g}$ for the reduction of mental problems; a special recommendation for pregnant women is of at least 300mg DHA per day [18]. According to the American Heart Association Dietary Guidelines, published by the American Heart Association in 2017,2 servings (200g) of fish (especially fatty fish) are recommended per week and of ALA 1.5-3g per day, which is equivalent to 0.6 to $1-2 \%$ omega-3 [1].

The Food and Agriculture Organization of the United Nations (FAO) recommends that $1-2 \%$ of the total calories ingested daily should come from omega-3 fatty acids, and less than $30 \%$ should be made up of other fats [19]. Other institutions recommend different variations of consumption of EPA, DHA and ALA. The International Society for the Study of Fatty Acids and Lipids recommends EPA and DHA intake greater than or equal to $500 \mathrm{mg} /$ day, and $0.7 \%$ of the daily calories intake of ALA; the United Kingdom Scientific Advisory Committee on Nutrition recommends values greater than 
$200 \mathrm{mg} /$ day of total polyunsaturated fatty acids [20-21]. According to the World Health Organization the dietary recommendation of omega-3 for primary prevention of cardiovascular diseases should be at least $500 \mathrm{mg} /$ day of the combination EPA and DHA, while $1 \mathrm{~g} /$ day is recommended for patients with cardiovascular diseases [22].

The new Brazilian Guideline for Dyslipidemia and Atherosclerosis Prevention, issued by Sociedade Brasileira de Cardiologia (SBC, Brazilian Society of Cardiology), indicates that the daily consumption of omega-3 is an important factor in the prevention of atherosclerosis and cardiovascular diseases [23]. To this effect, the proportion to be used is 5-10\% monounsaturated fatty acids and $15 \%$ polyunsaturated fatty acids. Omega- 3 is considered an adjuvant in the treatment of hypertriglyceridemia, as the intake of omega-3 EPA and DHA between 2-4g/day, can reduce the concentration of triglycerides in the blood by up to $30 \%$. On the other hand, for people who are slightly hyperlipidemic or borderline, doses of $1.5 \mathrm{~g} /$ day help to reduce up to $51 \%$ the triglyceride levels. Still in Brazil, the Agência Nacional de Vigilância Sanitária (ANVISA, National Health Surveillance Agency), determines that food products containing omega-3 must contain at least $40 \mathrm{mg}$ of the combination of EPA and DHA in $100 \mathrm{~g}$ or $100 \mathrm{~mL}$ portion of the prepared food [24].

In this way, food enrichment can be an interesting alternative to increase consumption of omega-3. However, the incorporation of these nutrients, their stability and functionality until they are metabolized by the human body due to their high susceptibility to oxidative deterioration, is still challenging for the food industry; this is the reason why the encapsulation or other form of oil protection is essential for that purpose [25].

The use of nanotechnology in food is recent compared to the use in other areas, such as biomedical and information technology industries, in which nanotechnology is advancing rapidly in the manufacture of new materials. However, there are a number of opportunities to be explored for the development of food products with functional and nutraceutical characteristics [26].

We retrieved from the literature review, within the descriptors defined for the search, seven studies that mentioned nanoparticles to be incorporated as ingredients in food and reducing the oxidation of fatty acids in relation to the free active, or those in non-nano formulation. Table 1 presents the result of the search in which the active was evaluated with regard to oxidation and were incorporated into food products, such as: bread, fruit juice, milk, yogurt and meat. The most relevant information yielded by the studies reviewed is presented in the following table [27-33].

Nanoencapsulation is defined as a technology for encapsulating small bioactive compounds to produce stable formulations [7]. Nanoparticles are defined as particulate dispersions or solid particles which size range from 5-10Nm with a maximum size of $1000 \mathrm{n}$; however the average size of these particles is around $100-500 \mathrm{Nm}$ and are capable of dissolving, encapsulating or adsorbing drugs or nutrients in their structure [34-35]. The nanoparticles obtained by different methods usually after preparation have average diameters between 100 and 300 Nm and a low polydispersity index. Values of average particle diameter below $300 \mathrm{~nm}$ and polydispersity index values below 0.3 ensure homogeneity in the particle size distribution and reduced agglomeration [36].

The nanostructured systems most used in the studies covered by this review for the encapsulation of unsaturated fatty acids incorporated into food products were nanocapsules and nanoliposomes. Nanocapsules are particles coated with polymers that carry the active in their core, which can be liquid or solid (Figure 1A). They are small spheres with a uniform wall, which when produced for incorporation into food, are covered by biodegradable polymers [37]. In addition, nanoparticles can improve the bioavailability of bioactive compounds, since the nanoscale size of particles with 
Table 1. Main characteristics of nanoformulations incorporated in food products addressed in the publications included in this review.

\begin{tabular}{|c|c|c|c|c|}
\hline Product & Nanoformulation used & Nanoparticles characteristics & Main findings & Reference \\
\hline Bread & Nanocapsule & $\begin{array}{l}\text { Particle size: } 20.05 \pm 2.40 \mu m \\
\text { PDIa: uninformed } \\
\text { Source of omega: flaxseed } \\
\text { oil }\end{array}$ & $\begin{array}{l}\text { Nanoformulation did not alter the sensory } \\
\text { properties of food; } \\
\downarrow \text { unpleasant taste and } \uparrow \text { in the sensorial quality } \\
\text { of the product in relation to the same amount of } \\
\text { omega- } 3 \text { contained in the free oil; } \\
\downarrow \text { fatty acid thermoxidation during cooking. }\end{array}$ & {$[27]$} \\
\hline $\begin{array}{l}\text { Bread and } \\
\text { milk }\end{array}$ & Nanoliposome & $\begin{array}{l}\text { Particle size: } 73.2 \pm 18.1 \mathrm{Nm} \\
\text { PDI: } 0.216 \\
\text { Source of omega: fish oil }\end{array}$ & $\begin{array}{l}\downarrow \text { peroxide and anisidine values in nanoliposome } \\
\text { samples compared to other non-nano samples; } \\
\uparrow \text { stability during storage ( } 3 \text { and } 7 \text { days for } \\
\text { milk and bread, respectively) and without any } \\
\text { unpleasant detectable fish flavor }\end{array}$ & [28] \\
\hline Bread & Nanoliposome & $\begin{array}{l}\text { Particle size: } 339.2 \mathrm{Nm} \\
\text { PDI: } 0.426 \\
\text { Source of omega: fish oil }\end{array}$ & $\begin{array}{l}\uparrow \text { nutritional value of bread } \\
\downarrow \text { lipid oxidation } \\
\text { improvement of sensory characteristics, without } \\
\text { changes for } 25 \text { days, when compared to bread } \\
\text { with free oil. }\end{array}$ & [29] \\
\hline Fruit juice & Nanocapsule & $\begin{array}{l}\text { Particle size: } 232.3 \mathrm{Nm} \\
\text { PDI: uninformed } \\
\text { Source of omega: fish oil }\end{array}$ & $\begin{array}{l}\text { The results of the study showed that the use of } \\
\text { essential fatty acids in food formulations can be } \\
\text { achieved by nanoencapsulation with the protein- } \\
\text { polysaccharide complex }\end{array}$ & [30] \\
\hline Milk & Nanocapsule & $\begin{array}{l}\text { Particle size: } 219 \mathrm{Nm} \\
\text { PDI: } 0.24 \\
\text { Source of omega: oleic acid }\end{array}$ & $\begin{array}{l}\downarrow \text { total oxidation products formed } \\
\downarrow \text { unpleasant taste during the } 16 \text { days of milk } \\
\text { storage at } 4^{\circ} \mathrm{C}\end{array}$ & [31] \\
\hline Yogurt & Nanoliposome & $\begin{array}{l}\text { Particle size: } 409 \mathrm{Nm} \\
\text { PDI: } 0.557 \\
\text { Source of omega: fish oil }\end{array}$ & $\begin{array}{l}\downarrow \text { acidity and peroxide value when compared to } \\
\text { yogurt fortified with free oil } \\
\downarrow \text { the } \mathrm{pH} \text { of the yogurt over the } 21 \text { days, however } \\
\text { in the sample with the fish oil liposomes the } \\
\text { reduction was significantly lower }\end{array}$ & [32] \\
\hline Meat & Nanocapsule & $\begin{array}{l}\text { Size: } \sim 350 \mathrm{Nm} \\
\text { PDI: } \sim 0.3 \\
\text { Source of omega: fish oil }\end{array}$ & $\begin{array}{l}\uparrow \text { Long-chain PUFAs, especially omega-3, after } \\
\text { ultrasound treatment. } \\
\downarrow \text { proportion of omega-6/omega-3 in pork } \\
\text { meat after ultrasound treatment, indicating an } \\
\text { improved fatty acid profile in pork meat. }\end{array}$ & [33] \\
\hline
\end{tabular}

Note: apDI: Polydispersity Index. PUFAs: Polyunsaturated Fatty Acids.

larger surface areas can make them more favorable for interaction with intestinal epithelial cells, of particular importance for food applications and are expected to improve delivery properties, solubility, protection from degradation (oxidation), prolonged residence time in the gastrointestinal tract and efficient absorption of bioactive compounds by cells. For food applications, it is necessary to prepare nanoparticles with food-grade delivery materials, such as chitosan and whey protein, to meet safety requirements $[31,38,39]$. Nanoliposomes can be defined as single or multilayer vesicles, which include the complete encapsulation of an aqueous phase, or interspersed with the lipid phases, with the water-soluble active in a phospholipid-based membrane (Figure 1B) [40]. Some formulations use a fat-soluble active, incorporating it into the lipid membrane, as is the case with oils used in the studies included in this review. Hydrophobic/hydrophilic interactions between the lipid/lipid and lipid/ water interfaces are responsible for the formation of liposomes [41-43].

Zimet and Livney [44] developed nanocapsules of $\beta$-lactoglobulin, the main whey protein, combined with pectin to encapsulate DHA, with good colloidal stability and average particle size of $100 \mathrm{Nm}$. Nanocomplex encapsulation of $\beta$-lactoglobulin with pectin provided good protection against DHA degradation during an accelerated stress testing with only about $5-10 \%$ loss during $100 \mathrm{~h}$ at $40^{\circ} \mathrm{C}$, compared to about $80 \%$ loss with free DHA. Another study, developed by Ha, Lee and Lee 


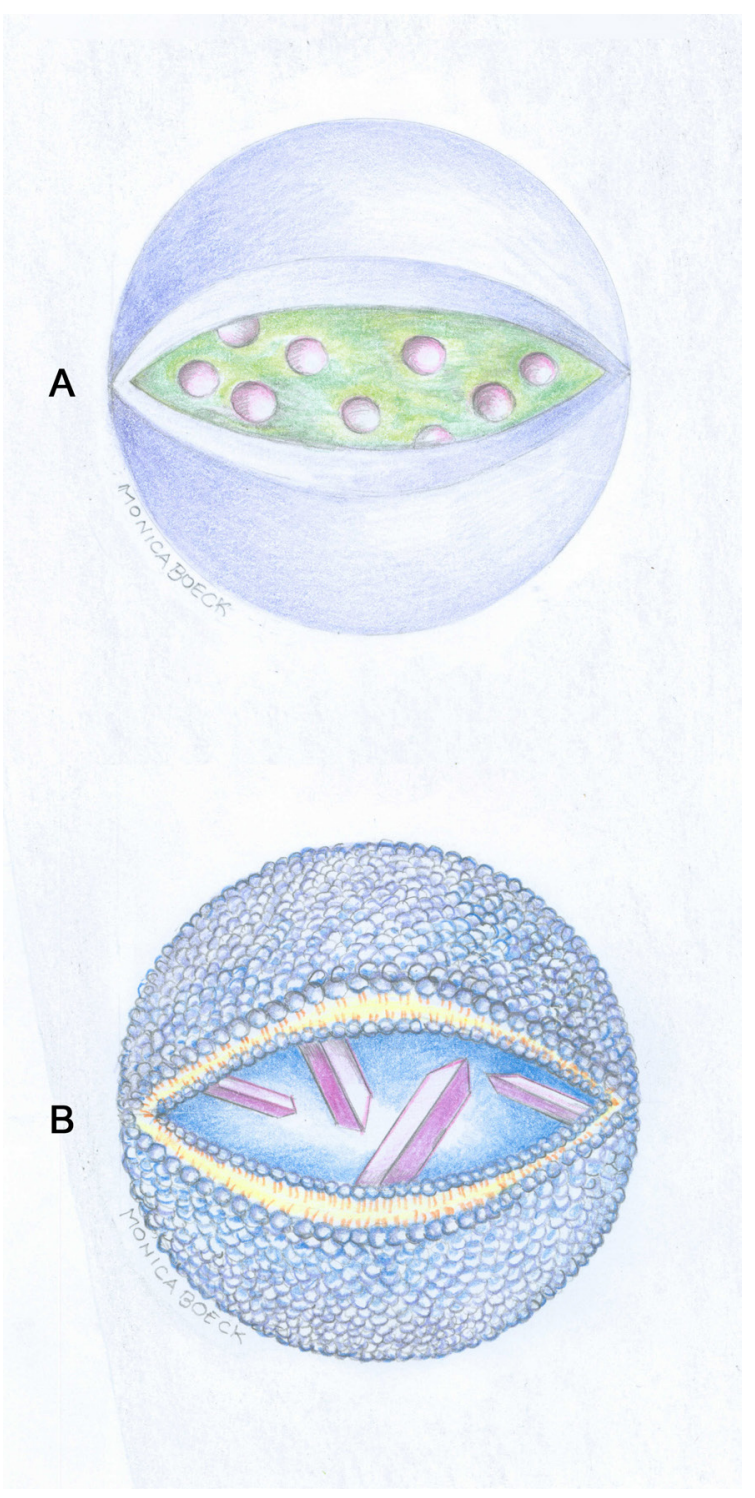

Figure 1. Representation of nanostructures.

Note: (A) Nanocapsule: oily core surrounded by a polymeric capsule; (B) Nanoliposome: aqueous core surrounded by a lipid membrane that could be multilamellar. Design by Mônica Boeck.

[31], aimed to produce a water-based nanocapsule for a delivery system that could encapsulate DHA at levels similar to the levels found in human milk (which varies 20-fold among the non-Western and Western populations, associated with fish consumption, ranging from $0.06-1.4 \% / \mathrm{kg}$ ) and to investigate the effects of particle treatment at low storage temperature $\left(4^{\circ} \mathrm{C}\right)$ [31]. The particles were produced by combining $\beta$-lactoglobulin with chitosan combined with oleic acid (in different proportions). $\beta$-lactoglobulin was used because it is a food product that has the ability to bind to DHA and act as an antioxidant, thus reducing the oxidation of the fatty acid [31]. More than 200mg/L of DHA have been successfully encapsulated in $250 \mathrm{Nm} \beta$-lactoglobulin/chitosan-oleic acid nanoparticles, stable at temperatures below $25^{\circ} \mathrm{C}$, resulting in DHA encapsulation efficiency of 77.6 to $82.0 \%$, an amount of DHA greater than that found in breast milk. Skimmed milk supplemented with free 
DHA or nanoencapsulated DHA was evaluated with regard to lipoperoxidation. DHA-nano exhibited a decrease in the total value of the peroxide formed (primary oxidation products) and p-anisidine (secondary oxidation products); consequently, a reduction in the development of unpleasant taste compounds in milk during 16 days at $4^{\circ} \mathrm{C}$ was observed. The authors conclude that $\beta$-lactoglobulin/ chitosan-oleic acid nanoparticles may increase DHA oxidation stability suggesting that they can be used as an aqueous-based delivery system for the fortification with DHA of fat-free dairy foods.

However, the application of DHA in fat-free dairy foods is often limited due to its poor solubility in water and high sensitivity to oxidative degradation. The oxidation of polyunsaturated fatty acids results in the development of primary oxidation products called lipid peroxides. Once lipid peroxides are produced, a free radical chain reaction is propagated, resulting in the formation of different secondary oxidation products, including aldehydes, which can contribute to the development of undesirable flavor in the food. However, most studies assess the development of lipid carriers, including nanoemulsions, which would not be appropriate for fat-free foods. The development of an aqueous-based delivery system such as nanocapsules may be interesting to supplement DHA in fat-free dairy foods [31].

The Ojagh and Hasani study [29] aimed to produce nano-liposomes containing fish oil and to evaluate the physical properties and oxidative stability for 25 days under refrigerated conditions, to investigate the potential of incorporating fish oil in nanoliposomes in bread, and also to verify its effects on the characteristics and sensory properties of bread. The nanoliposomes had a particle size of about $339.2 \mathrm{Nm}$ and a PDI of 0.426 . The fish oil encapsulation efficiency in nanoliposomes was on average $90.12 \pm 0.27 \%$. Nanoparticulate fish oil showed better stability against lipid oxidation compared to free oil during 25 days storage under refrigeration. The technological and sensory evaluation of the bread showed that the bread enriched with nanoliposomes generated a greater volume of bread, good crumb structure and reduced rancidity compared to bread enriched with free oil. The authors suggest that the good qualities of bread enriched with nanoliposomes may be due to the presence of lecithin in the formulation used as an emulsifier, which interacts with the amylose and amylopetine chains, giving greater stability to the dough and reducing its hardness. The study showed that the incorporation of fish oil in nanoliposomes induced positive effects on the technological properties of bread, in addition to good sensory acceptance. The additive, besides increasing the nutritional value of bread, improving sensory characteristics, caused a reduced lipid oxidation when incorporated into nanoparticles.

Fish oil enriched with EPA and DHA (10\%) was incorporated into nanoliposomes to be used in the enrichment of milk and bread [28]. According to that study, the prepared liposomes had an average particle size in the range of $73.2 \pm 18.1 \mathrm{Nm}$ and a polydispersity index equal to 0.216 . Its application was compared with oils both free and microencapsulated, all of them with polyunsaturated fatty acids, where the recovery of EPA and DHA was determined after storage (milk and bread, respectively). At the end of 7 days of bread storage, the recovery of polyunsaturated fatty acids was greater in the food enriched with nanoliposomes>microcapsules $>$ free oil. The same was observed for milk after 3 days storage. As for the sensory evaluation, the results showed that the samples enriched with fish oil plus non-vesiculated nor microparticulate EPA and DHA released a significant fish flavor, while this odor and flavor was not verified in bread enriched with nanoliposomes. In addition, lower values of peroxide and anisidine were observed in samples of nanoliposomes compared to other samples. Losses in cooking and pasteurization must be taken into account when informing nutritional data about these products enriched with omega-3 polyunsaturated fatty acids. 
Overall, the results of the sensory evaluation demonstrated that milk and bread enriched with omega-3 nanoliposome exhibited high stability during storage (3 and 7 days for milk and bread, respectively) and without the development of any unpleasant detectable fish flavor, showing that this is an effective and reproducible method for the application of omega-3 polyunsaturated fatty acids in the food system. Generally, the undesirable taste and odor are due to the oxidation of fatty acids, which are formed in the food from the development of oxidation by-products.

In the study by Ghorbanzade et al. [32], nanoliposomes with fish oil were used to fortify yogurt. The physical-chemical properties of the yogurt produced, including $\mathrm{pH}$, acidity, syneresis, fatty acid composition, peroxide value, as well as sensory tests were investigated for 3 weeks at $4^{\circ} \mathrm{C}$. The nanoliposomes had an average particle size around $409 \mathrm{Nm}$ and a PDI of 0.557 . The encapsulation of fish oil in nanoliposomes resulted in a significant reduction of acidity and peroxide value when compared to yogurt fortified with free oil, or liposomes without oil (control liposomes). The yogurt $\mathrm{pH}$ decreased over the 21 days; however in the sample containing fish oil liposomes the $\mathrm{pH}$ reduction was significantly lower, probably due to the fact that the oil, when protected, undergoes less oxidation of fatty acids, and consequently, produces a lower level of acidity [45]. The results of gas chromatography revealed that after 21 days the yogurt with nanoliposomes with fish oil had a higher DHA and EPA content than yogurt containing free fish oil, thus showing less oxidation.

The omega-3 nanoencapsulation in food includes reducing the interactions of the nucleus with environmental factors, thus reducing changes that may result in loss of aroma, undesirable taste, color change or nutritional value, in addition to providing greater functionality and product stability, including controlled release during storage at different temperatures [46]. The stability in these studies was tested from 3 to 25 days, showing an increase in encapsulation efficiency and a decrease in the oxidation of omega-3 fatty acids, a decrease in the formation of peroxides. Studies that tested the sensory properties of foods, indicate improvement in the taste and odor of these products when the fatty acids were incorporated into nanoparticles.

The nanostructured system can still be considered a new technology in the food area and the advantages and limitations of its use on an industrial scale are not fully understood. Some nanomaterials for industrial application may contain heavy metals that are known to be toxic, except for those biodegradable used in the formulation composition for food. In addition, due to their small size, these compounds interact with both the external and physiological environments. The challenges are to obtain more information about the properties and risks of these nanomaterials, their application on an industrial scale and their acceptance by consumers $[6,7,46]$.

Thus, in view of the potential for the application of nanotechnology in the food industry, what was found so far regarding the development of new products that use nanotechnology for the encapsulation of polyunsaturated fatty acids is still considered insufficient. Different methodologies were identified, without the use of a standard protocol that would favor large-scale replication and that indicated the real benefits for human and/or animal health. Such limitations pose difficulties but drive towards a regulation, based on scientific information on health effects, currently released in international bodies guidelines for better monitoring of production, application and effects. In fact, more research is needed related to the application of these products as well as toxicity assessments, both with regard to the environment and to human health.

\section{CONCLUSION}

Nanotechnology is explored due to its features that can generate better protection for bioactive compounds vulnerable to environmental conditions, such as unsaturated fatty acids of 
great functional importance. Thus, nanoencapsulation of mono and/or polyunsaturated fatty acids is a promising system to promote the maintenance of their nutraceutical properties, reducing oxidation and improving their bioavailability, thus improving therapeutic efficacy. However, there are several methodologies in the literature being tested, thus making it difficult to identify which one would be the most efficient (or suitable for a given food product) in protecting against oxidation, high temperatures and shelf life. Studies vary considerably according to the type of nanoparticle, the particle size, the amount of surfactants and emulsifiers, the amount of encapsulated oil and the stability time, which makes it impossible to decide which would be the best methodology for encapsulating unsatured fatty acids, especially for food products use. Thus, more studies should be carried out to define a protocol based on regulations for a better nanoencapsulation of unsaturated fatty acids for use in functional foods, as well as to define if there is any toxicity present and any beneficial effects.

\section{REFERE N CES}

1. Sacks FM, Lichtenstein AH, WU JHY, Appel LJ, Creager MA, Kris-Etherton PM, et al. Dietary fats and cardiovascular disease: a presidential advisory from the american heart association. Circulation. 2017;136:e1-e23. https://doi.org/10.1161/CIR.0000000000000510

2. Oliveira L, Poínhos R, Sousa F, Silveira MG. Construção e validação de um questionário para avaliação da percepção sobre alimentos funcionais. Acta Port Nutr. 2016;7:14-7.

3. Pinheiro AC, Ângelo $M$, Augusto A. Nanotecnologia como ferramenta para produzir novos alimentos funcionais: vantagens e precauções. 2013;22-6.

4. Zimet P, Rosenberg D, Livney YD. Re-assembled casein micelles and casein nanoparticles as nano-vehicles for $\omega-3$ polyunsaturated fatty acids. Food Hydrocoll. 2011;25:1270-6.

5. Almeida ACS, Franco EAN, Peixoto FM, Pessanha KLF, Melo NR. Aplicação de nanotecnologia em embalagens de alimentos. Polímeros. 2015;25:89-97.

6. Cardoso Gomes R, Pastore V, Martins O, Biondi G. Aplicações da nanotecnologia na indústria de alimentos: uma revisão. Rev Bras Hig Sanidade Anim. 2015;9:1-8.

7. Hardy A, Benford D, Halldorsson T, Jeger MJ, Knutsen HK, More S, et al. Guidance on risk assessment of the application of nanoscience and nanotechnologies in the food and feed chain: part 1, human and animal health. Efsa J. 2018[in press];16. https://doi.org/10.2903/j.efsa.2018.5327

8. Jeevanandam J, Barhoum A, Chan YS, Dufresne A, Danquah MK. Review on nanoparticles and nanostructured materials: history, sources, toxicity and regulations. Beilstein J Nanotechnol. 2018;9:1050-74.

9. Hamad AF, Han J-H, Kim B-C, Rather IA. The intertwine of nanotechnology with the food industry. Saudi J Biol Sci. 2018;25:27-30.

10. Davidov-Pardo G, Joye IJ, McClements DJ. Food-grade protein-based nanoparticles and microparticles for bioactive delivery: fabrication, characterization, and utilization. Adv Protein Chem Struct Biol. 2015;98:293-325.

11. Chikwanha OC, Vahmani P, Muchenje V, Dugan ERD, Mapiye C. Nutritional enhancement of sheep meat fatty acid profile for human health and wellbeing. Food Res Int. 2018;104:25-38.

12. Tortosa-Caparrós E, Navas-Carrillo D, Marín F, Orenes-Piñero E. Anti-inflammatory effects of omega 3 and omega 6 polyunsaturated fatty acids in cardiovascular disease and metabolic syndrome. Crit Rev Food Sci Nutr. 2017;57:3421-9.

13. Guimarães-Inácio A, Francisco CRL, Rojas VM, Leone RS, Valderrama P, Bona E, et al. Evaluation of the oxidative stability of chia oil-loaded microparticles by thermal, spectroscopic and chemometric methods. Lebensm Wiss Technol. 2018;87:498-506.

14. Department of Health and Human Services (United States). Dietary guidelines for Americans: 2015-2020. Washington: Department; 2015 [cited 2019 Sep 6]. Available from: http://health.gov/dietaryguidelines/2015/ guidelines/ 
15. Dyerberg J, Bang HO. Haemostatic function and platelet polyunsaturated fatty acids in Eskimos. Lancet. $1979 ; 2: 433-5$.

16. Asbaghi O, Choghakhori R, Abbasnezhad A. Effect of Omega-3 and vitamin E co-supplementation on serum lipids concentrations in overweight patients with metabolic disorders: a systematic review and meta-analysis of randomized controlled trials. Diabetes Metab Syndr. 2019;13:2525-31.

17. Santos RD, Gagliardi ACM, Xavier HT, Magnoni CD, Cassani R, Lottenberg AMP, et al. I Diretriz sobre o consumo de gorduras e saúde cardiovascular. Arq Bras Cardiol. 2013;100:1-40.

18. World Health Organization. Healthy diet WHO. Geneva: Organization; 2015 [cited 2019 Sep 6]. Available from: https://www.who.int/nutrition/publications/nutrientrequirements/healthydiet_factsheet/en/

19. Food and Agriculture Organization of The United Nations. Fats and fatty acids in human nutrition. Report of an expert consultation. Fao Food Nutr Pap. 2010 [cited 2019 Sep 6];91:1-166. Available from: http://foris. fao.org/preview/25553-0ece4cb94ac52f9a25af77ca5cfba7a8c.pdf

20. International Society for the Study of Fatty Acids and Lipids. Proceedings of the 6th Congress of the International Society for the Study of Fatty Acids and Lipids. Prog Lipid Res. 2004;43:382.

21. Scientific Advisory Committee on Nutrition (United Kindom). Satured fats and health. London: Committee; 2019 [cited 2019 Sep 6]. Available from: https://www.gov.uk/government/publications/saturated-fats-andhealth-sacn-report

22. World Health Organization. Essential nutrition actions: mainstreaming nutrition throughout the life-course. Geneva: Organization; 2019 [cited 2019 Sep. 6]. Available from: https://apps.who.int/iris/bitstream/hand le/10665/326261/9789241515856-eng.pdf?ua=1

23. Faludi A, Izar M, Saraiva J, Chacra APM, Bianco HT, Afiune Neto A, et al. Atualização da diretriz brasileira de dislipidemias e prevenção da aterosclerose. Arq Bras Cardiol. 2017;109:1-76.

24. Ministério da Saúde (Brasil). Resolução da Diretoria Colegiada-RDC n. 54, de 12 de novembro de 2012. Brasília: Ministério; 2012.

25. Timilsena YP, Vongsvivut J, Adhikari R, Adhikari B. Physicochemical and thermal characteristics of Australian chia seed oil. Food Chem. 2017;228:394-402.

26. Assis LM, Zavareze ER, Prentice-Hernández C, Souza-Soares, Leonor A. Revisão: características de nanopartículas e potenciais aplicações em alimentos. Bra J Food Technol. 2012;15:99-109.

27. Gökmen V, Mogol BA, Lumaga RB, Fogliano V, Kaplun Z, Shimoni E, et al. Development of functional bread containing nanoencapsulated omega-3 fatty acids. J Food Eng. 2011;105:585-91.

28. Rasti B, Erfanian A, Selamat J. Novel nanoliposomal encapsulated omega-3 fatty acids and their applications in food. Food Chem. 2017;230:690-6.

29. Ojagh SM, Hasani S. Characteristics and oxidative stability of fish oil nano-liposomes and its application in functional bread. J Food Meas Charact. 2018;12:1084-92.

30. llyasoglu H, El SN. Nanoencapsulation of EPA/DHA with sodium caseinate-gum arabic complex and its usage in the enrichment of fruit juice. Lwt Food Sci Technol. 2014;56:461-8.

31. Ha HK, Lee MR, Lee WJ. Oxidative stability of DHA in $\beta$-lactoglobulin/oleic acid-modified chitosan oligosaccharide nanoparticles during storage in skim milk. Lwt Food Sci Technol 2018;90:440-7.

32. Ghorbanzade T, Jafari SM, Akhavan S, Hadavi R. Nano-encapsulation of fish oil in nano-liposomes and its application in fortification of yogurt. Food Chem. 2017;216:146-52.

33. Ojha KS, Perussello CA, García CÁ, Kerry JP, Pando D, Tiwari BK. Ultrasonic-assisted incorporation of nanoencapsulated omega-3 fatty acids to enhance the fatty acid profile of pork meat. Meat Sci 2017;132:99-106.

34. Olawoyin R. Nanotechnology: the future of fire safety. Saf Sci. 2018;110:214-21.

35. Mohanraj VJ, Chen Y. Nanoparticles: a review. Trop J Pharm Res. 2007;5:561-73.

36. Clayton KN, Salameh JW, Wereley ST, Kinzer-Ursem TL. Physical characterization of nanoparticle size and surface modification using particle scattering diffusometry. Biomicrofluidics. 2016;10:054107. https://doi. org/10.1063/1.4962992

37. Vijeth S, Heggannavar GB, Kariduraganavar MY. Encapsulating wall materials for micro-/nanocapsules. In: Salaün F. Microencapsulation: processes, technologies and industrial applications. London: IntechOpen; 2019. https://doi.org/10.5772/intechopen.82014 
38. Shtay R, Tan CP, Schwarz K. Development and characterization of solid lipid nanoparticles (SLNs) made of cocoa butter: a factorial design study. J Food Eng. 2018;231:30-41.

39. Santos VS, Braz BB, Silva AÁ, Cardoso LP, Ribeiro APB, Santana MHA. Nanostructured lipid carriers loaded with free phytosterols for food applications. Food Chem. 2019 [forthcoming];298. https://doi.org/10.1016/j. foodchem.2019.125053

40. Food and Drug Administration (United States). Guidance for industry: liposome drug products: chemistry manufacturing and controls, human pharmacokinetics and bioavailability. Federal Register. Silver Spring: Administration; 2002 [cited 2017 Dec 27]. Available from: http://www.fda.gov/Drugs/ GuidanceComplianceRegulatorylnformation/Guidances/default.htm

41. Katouzian I, Jafari SM. Nano-encapsulation as a promising approach for targeted delivery and controlled release of vitamins. Trends Food Sci Technol. 2016;53:34-48.

42. Assadpour E, Mahdi Jafari S. A systematic review on nanoencapsulation of food bioactive ingredients and nutraceuticals by various nanocarriers. Crit Rev Food Sci Nutr. 2019;59:3129-51.

43. Bahrami A, Delshadi R, Jafari SM, Williams L. Nanoencapsulated nisin: an engineered natural antimicrobial system for the food industry. Trend Food Sci Technol. 2019;94:20-31.

44. Zimet P, Livney YD. Beta-lactoglobulin and its nanocomplexes with pectin as vehicles for $\omega$-3 polyunsaturated fatty acids. Food Hydrocoll. 2009;23:1120-6.

45. Vieira JS, Sousa T, Rosas L, Lima A, Ronconi C, Mota C. Esterificação e transesterificação homogênea de óleos vegetais contendo alto teor de ácidos graxos livres. Quim Nova. 2017;41:10-6.

46. McClements DJ, Decker EA, Park Y, Weiss J. Structural design principles for delivery of bioactive components in nutraceuticals and functional foods. Crit Rev Food Sci Nutr. 2009;49:577-606. 